\title{
Article \\ Molecular Phylogeny of Trifolium L. Section Trifolium with Reference to Chromosome Number and Subsections Delimitation
}

\author{
Hanan I. Sayed Ahmed ${ }^{1}$, Abdelfattah Badr ${ }^{2}(D)$, Hanaa H. El-Shazly ${ }^{3}$, Linda Watson $^{4}$ (D) Ahmed S. Fouad ${ }^{5, *(D)}$ \\ and Faten Y. Ellmouni ${ }^{6}$ (D)
}

Citation: Ahmed, H.I.S.; Badr, A.; El-Shazly, H.H.; Watson, L.; Fouad, A.S.; Ellmouni, F.Y. Molecular Phylogeny of Trifolium L. Section Trifolium with Reference to

Chromosome Number and Subsections Delimitation. Plants 2021 10, 1985. https://doi.org/10.3390/ plants10101985

Academic Editors: Victoria Shneyer, Alexander Rodionov and Alex Troitsky

Received: 8 July 2021

Accepted: 15 September 2021

Published: 23 September 2021

Publisher's Note: MDPI stays neutral with regard to jurisdictional claims in published maps and institutional affiliations.

Copyright: (c) 2021 by the authors. Licensee MDPI, Basel, Switzerland. This article is an open access article distributed under the terms and conditions of the Creative Commons Attribution (CC BY) license (https:/ / creativecommons.org/licenses/by/ $4.0 /)$.
1 Botany and Microbiology Department, Faculty of Science, Tanta University, Tanta 31527, Egypt; hanan.ahmed@science.tanta.edu.eg

2 Botany and Microbiology Department, Faculty of Science, Helwan University, Cairo 117900, Egypt; abadr@science.helwan.edu.eg

3 Department of Biological Sciences and Geology, Faculty of Education, Ain Shams University, Cairo 11341, Egypt; hhelshazly@yahoo.com

4 Department of Plant Biology, Ecology, and Evolution, Oklahoma State University, Stillwater, OK 74078-3013, USA; linda.watson10@okstate.edu

5 Botany and Microbiology Department, Faculty of Science, Cairo University, Giza 12613, Egypt

6 Botany Department, Faculty of Science, Fayoum University, Fayoum 63514, Egypt; fyl00@fayoum.edu.eg

* Correspondence: ahmedsfouad@yahoo.com

Abstract: The genus Trifolium is one of the largest genera of the legume family Fabaceae with ca. 255 species. The genus is divided into eight sections; the section Trifolium is a major section of the genus, comprising 73 species mainly distributed in the Mediterranean region. We used nuclear ribosomal DNA internal transcribed spacer (ITS) and morphological variation to reconsider the delimitation and phylogenetic relationships of species in the section Trifolium with reference to chromosomal variations. Bayesian analysis of ITS data delimited the species as three clades based on the analysis of ITS sequence and informative indels in combination with morphological variation. The phylogeny of the species by different analyses methods does not support their current delimitation in 17 subsections. The basic chromosome number $x=8$ is the number for the genus Trifolium, from which $x=7,6$ and 5 were derived through successive aneuploidy events. With reference to the distribution of these numbers in the species of the section Trifolium, species in clade III and clade II are more evolved than species in clade I.

Keywords: Trifolium; phylogeny; ITS sequence; section Trifolium; chromosome number

\section{Introduction}

The clover genus Trifolium L. is one of the most important genera of the family Fabaceae. It comprises approximately 255 herbaceous, perennial and annual species distributed in different geographic regions, particularly in the Mediterranean region, East Europe, Eurasia, the highlands of eastern Africa and western North America [1-3]. The economic importance of the genus is demonstrated by the wide growth of at least 16 species as livestock forage and green manure crops [2], and by the capacity of over 125 species to fix nitrogen through root nodulation by the bacterium Rhizobium leguminosarum biovar. Trifolii [4]. Fertile interspecific hybrids are difficult to achieve in Trifolium [5], and only succeed between closely related species [6-9]. Williams et al. [10] supported the hypothesis that a diploid alpine species (T. pallescens) mated with a diploid coastal species (T. occidentale) to produce tetraploid T. repens. This has spurred interest in the evaluation of the agronomic potential of locally utilized and currently uncultivated species as a potential genetic resource for crops [11].

Most contemporary classifications treat Trifolium sensu lato as one large genus of eight sections [12-14], of which six are restricted to the Old World (Chronosemium, Mistyllus, 
Paramesus, Trichocephalum, Trifolium, Vesicaria), one to the New World (Involucrarium) and one occurs in both hemispheres (Lotoidea). The later section comprises over 95 species and has traditionally been considered ancestral to all other sections due to its worldwide distribution and morphological heterogeneity $[13,14]$.

The Trifolium section has a native distribution throughout continental Europe, extending to Eurasia and south to North Africa. Species of this section show diverse specializations in seed dispersal mechanisms [14]. The section is considered one of the most derived sections in the genus on the basis of several features including a relatively large proportion of annual species, predominantly diploid species with a tendency towards descending aneuploidy $[15,16]$, highly specialized seed dispersal mechanisms, a reduction to a single-seeded pod [14] and heterogeneity in seed proteins [17].

The available literature about the subsectional delimation of the section Trifolium is contradictory. Zohary and Heller [14] proposed 17 subsections of one to ten species each. However, this sub-sectional delimitation has been found incongruent, with variation in seed protein electrophoretic patterns and the interspecific relationships as judged by the ability of species to cross [6-8].

Molecular phylogeny of Old World Trifolium species showed the Trifolium section to be polyphyletic, and the placement of the Mediterranean section Chronosemium (21 species) remained unresolved with conflicting hypotheses such as being derived from within the section Trifolium in a nrDNA phylogeny vs. sister to the entire genus in a cpDNA phylogeny [16]. Ellison et al. [1] provided a comprehensive systematic revision of the genus Trifolium using parsimony and Bayesian phylogenetic analyses based on nuclear ribosomal DNA internal transcribed spacer and chloroplast $t r n \mathrm{~L}$ intron sequences. The authors proposed dividing the genus into two subgenera, subg. Chronosemium and subg. Trifolium; the latter was divided into eight sections which are not in agreement with the sub-sectional delimitations of Zohary and Heller [14]. The ancestral life history was also assumed to be annual in subg. Chronosemium and indefinite in subg. Trifolium. However, transitions between the annual and perennial habit are common [18].

Comparative seed characteristics of Trifolium species [19] and comparative analysis of qualitative anatomical traits [20] indicated some diagnostic characters for the identification of Trifolium sections, which contradict the sub-sectional delimitation based on molecular phylogeny. Moreover, the sub-sectional delimitation of species in the section Trifolium is not congruent with the number of clades resolved by Watson et al. [16] and by Ellison et al. [1]. The use of non-morphological types of information certainly adds to the informational content for plant classifications. However, they should be integrated with (but not substitute) morphological data [21]. Character states were also reconstructed from chromosomal variations using $2 \mathrm{n}=16$ as the ancestral chromosome number in Trifolium and an inferred 19 instances of aneuploidy and 22 of polyploidy in the genus [17,22]. All chromosome numbers reported for the whole genus are based on the basic numbers of $x=8,7,6$ and $5[14,15,23-26]$. These studies have indicated the changes in chromosome number as a major player in the evolution of Trifolium.

The internal transcribed spacer sequence (ITS) of the ribosomal DNA has been demonstrated to be an accurate source of information for examining molecular phylogeny in many plant families including the Fabaceae $[27,28]$. Indels in the ITS sequences are consistently present in most alternative alignments and are more reliable for phylogenetic analysis [29]. The ITS indels have been successfully applied in the genus Trifolium at the sectional level [1,16] and at the species level [30]. Jreisat and Laten [31] recommended ITS for accurate identification and labeling of plant germplasm and for basic genetic and evolutionary studies to avoid mislabeled or misidentified germplasm collections.

Therefore, the objective of the present study is to construct a phylogenetic relationship of species in the Trifolium sect. Trifolium aims to reconsider the sub-sectional delimitation of species in this section, based on a comprehensive sampling of species, ITS analysis and variation in selected morphological traits in the light of variations in chromosome numbers of the examined species. 


\section{Results}

Figure 1 is a phylogenetic tree expressing the classification of the species of the section Trifolium based on the ITS sequence and informative indels, using MrBayes 3.2 [32] applying Interactive Tree of Life (iTOL) tools [33]. This Figure illustrates that all species of the section Trifolium are clearly isolated from the two outgroups of Trigonella, i.e., Trigonella gladiata and Trigonella spinosum. The Trifolium species are divided into two major clades: clade I comprises 26 species and clade II 28 species, in addition to two minor clades, clade III of 4 species and clade IV of 2 species. Clade I with a strongly supported bootstrap value of 100 is differentiated into two subclades, one of 7 species and the other of 19 species. The seven species of the first subclade are T. alexandrinum, T. echinatum, T. scutatum, T. vavilovii, T. clypeatum, T. pallidum and T. pannonicum. In the second subclade, T. berytheum is grouped with the two samples of T. carmeli 1, 2, and T. meironense, while T. squarrosum is clustered with T. miegeanum and T. obscurum. The other 12 species in this subclade are differentiated as single branches (Figure 1). In clade II, T. latinum and T. ligusticum are separated as a small subclade and the other 26 species are differentiated into one large subclade of 15 species and four small subclades, one of four species (T. affine, T. arvense, T. bocconei and T. dalmaticum), one of three species (T. incarnatum, T. leucanthum, T. stellatum) and two small subclades of two species each, i.e., T. molinerii grouped with T. phleoides and T. striatum with T. wettsteinii (Figure 1). On the other hand, clade III contained T. haussknechtii, T. sylvaticum, T. trichopterum and T. hirtum, while T. cherleri and T. scabrum were clustered in clade IV. The colors of the tree branches indicate the bootstrap values representing the percentage for the separation of clades and species. These values clearly show that the delimitation of the species in the section Trifolium as four clades. The number between parenthesis after the species branches are the recorded chromosome numbers for the species. All species in clade I have a basic chromosome number of $x=8$ except T. purpureum and all are diploid with $2 \mathrm{n}=16$ except T. pannonicum $(2 \mathrm{n}=64,96,98 \sim 180)$. On the other hand, chromosome numbers based on $x=5, x=6$, and $x=7$ have been reported in fourteen species in clade II and all the six species in clades III and IV.

Figure 2 illustrates two phylogenetic trees of the species of the section Trifolium constructed using TreeGraph 2 [34] and generated by MrBayes, one based on analysis of ITS sequence and informative indels (Figure 2A) and the other on ITS sequence plus indels and morphlogical variation combined (Figure 2B); bootstrap values are represented on the branches. Similar species delimation was recorded in both trees that largely agree with that in Figure 1 except for grouping clades III and IV in a single clade in the tree based on both ITS sequence data and morphlogical variation. In both trees, clade I comprises 26 species and clade II 28 species. Clade I is divided into two major subclades based on the analysis of ITS data (Figure 2A), one comprises the same seven species isolated together and the other the same 19 species, differentiated as in Figure 1. Clade I in the tree based on the combined ITS and morphological data analysis (Figure 2B) comprises the same 26 species and most of the subclades are as recognized in Figures 1 and 2A too. However, in Figure 2B, the following species are recognized as single branches: T. dichroanthum, T. vavilovii and T. scutatum, while T. pallidum and T. pannonicum form a small subclade. Of the remaining species, T. alexandrinum, T. echinatum and T. clypeatum are clustered from the other eighteen species, which are differentiated as one large subclade of seven species (T. angustifolium 1 and 2, T. purpureum, T. leucanthum, T. palaestinum, T. apertum and T. canscens) and a subclade of the four species T. berytheum, T. carmeli 1 and 2, and T. meironense). The remaining seven species are differentiated as T. caucasicum, one subclade of T. plebeium, T. dasyrum and T. constantinopolitanum and another of T. miegeanum, T. obscurum and T. squarrosum. The clustering of these species is congruent with their clustering in Figure 1. 


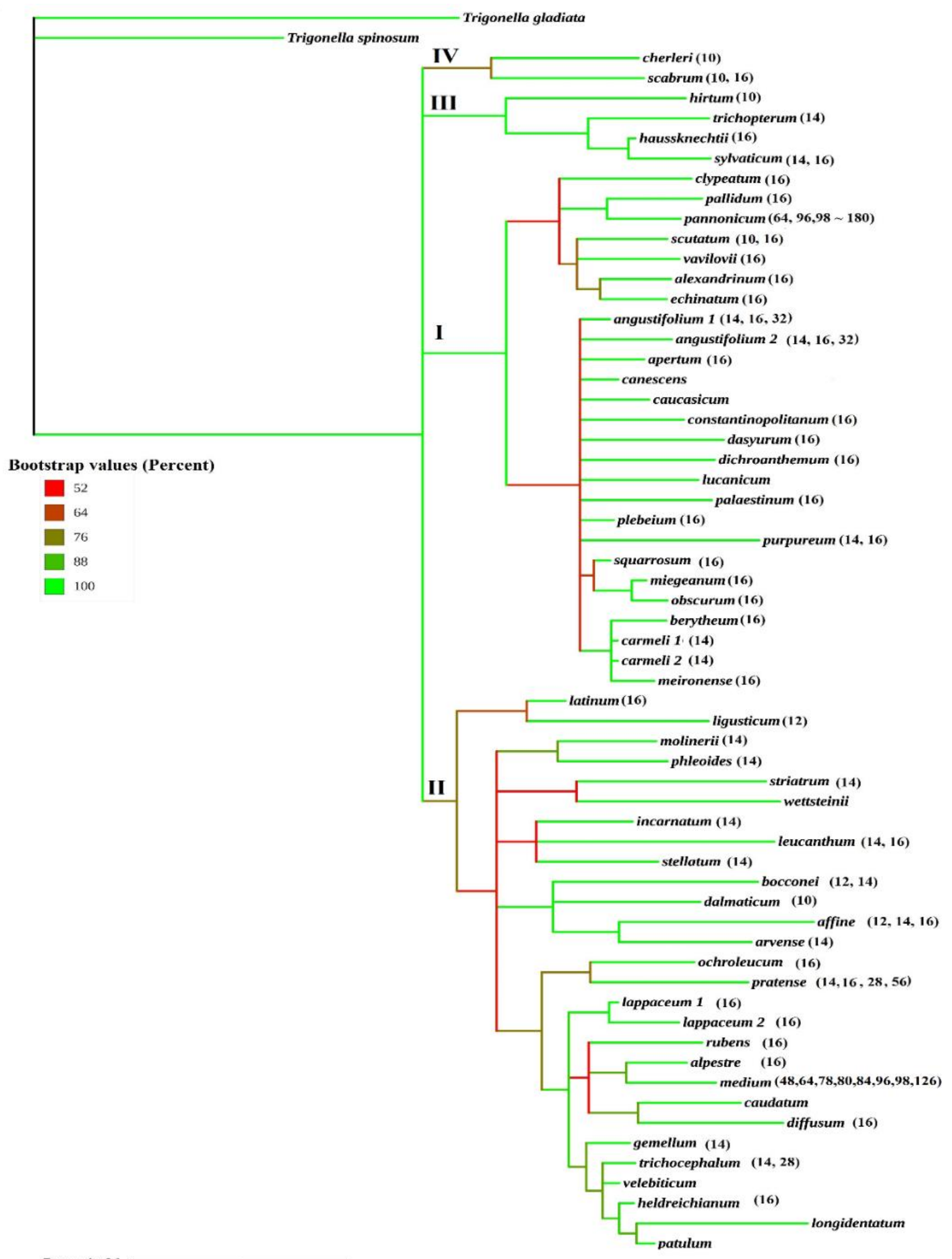

Figure 1. Phylogenetic tree expressing the classification of the species of the section Trifolium based on the ITS sequence and informative indels using MrBayes software and applying the Interactive Tree of Life (iTOL) tools. The colors of lines indicate the bootstrap value (percentage) for the separation of clades as expressed in the tree. The delimitation of the species as four clades is supported by a bootstrap value. 
(A)

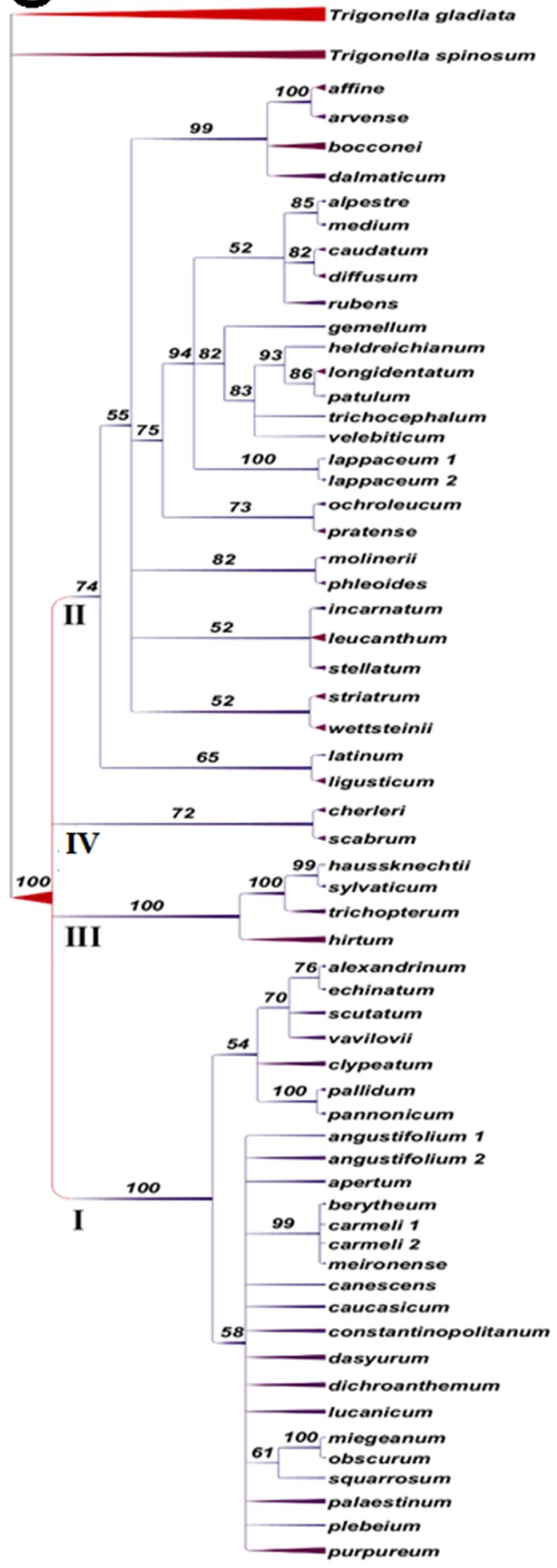

(B)

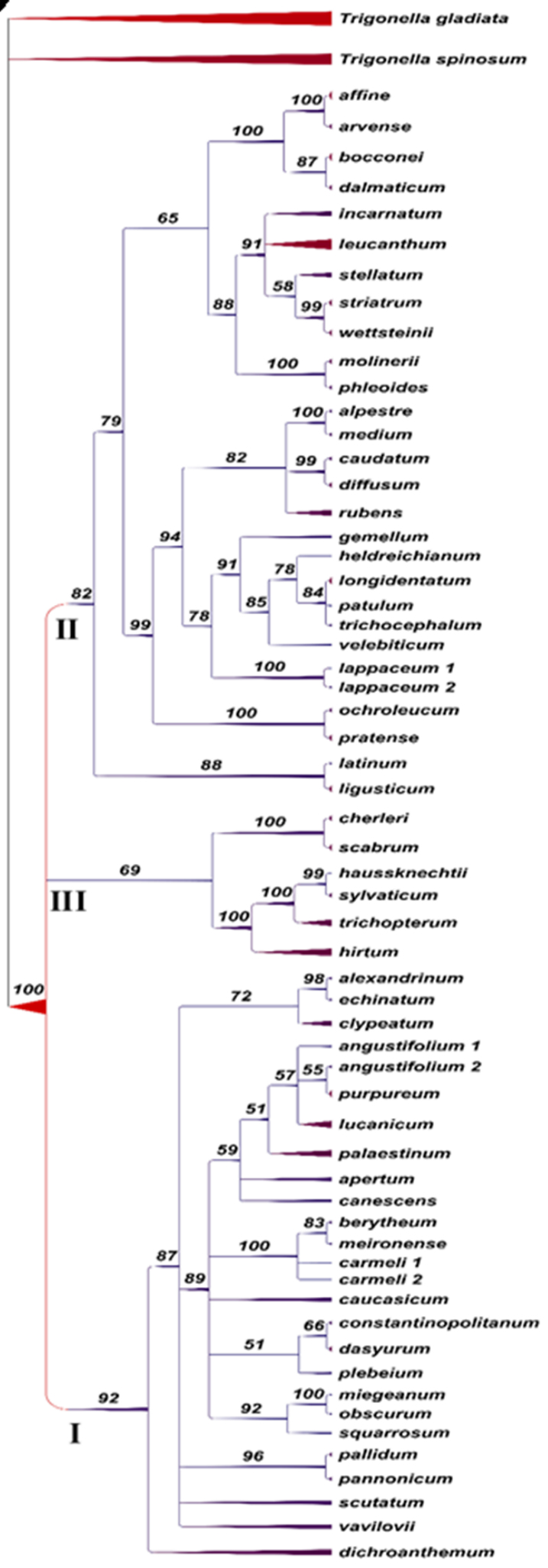

Figure 2. Two phylogenetic trees of the species in the section Trifolium constructed using MrBayes using TreeGraph 2, for visualizing phylogenetic trees. (A) tree based on ITS sequence and inormative indels and (B) tree based on combined ITS sequence plus indels and morphlogical variation. 
In clade II, T. latinum and T. ligusticum are delimited as a small subclade from the other species in both Figure 2A,B. The four species T. affine, T. arvense, T. bocconei, and T. dalmaticum form a separate subclade in Figure 2A based on ITS data analysis but form a subclade grouped with a second subclade of seven species in the tree based on the analysis of ITS and morphological data combined (Figure 2B). These species are T. incarnatum, T. leucanthum, T. stellatum, T. striatum, T. wettsteinii, in addition to T. molinerii and T. phleoides. The same species are recognized as three small clades in Figure 2A. A small subclade of T. ochroleucum and T. pratense is recognized in both Figure 2A,B. The remaining species are delimited as three subclades in both Figure 2A,B: one of T. lappaceum 1 and 2 and a second of the five species T. alpestre, T. medium, T. caudatum, T. diffusum and T. rubins, and the third of six species (Figure 2A,B). On the other hand, clade III of four species and clade IV of two species are clearly isolated in the ITS-based tree (Figure 2A). These clades are grouped into clade III in the tree based on the combined analysis of ITS data and morphological features (Figure 2B).

\section{Discussion}

In the current study, the analysis of ITS data alone and in combination with variation in morphological traits produced different delimitation of species in the section Trifolium compared with the previous subsectional assignment of species as proposed by Zohary and Heller [14] who divided the section Trifolium into 17 subsections (Table 1). The analysis of the ITS data delimited the species of the section Trifolium in four clades, of which clade I of 26 species is divided into two major subclades, one including seven species (T. alexandrinum, T. echinatum, T. scutatum, T. vavilovii, T. clypeatum, T. pallidum and T. pannonicum). The clustering of these species, except T. pallidum and T. pannonicum, is congruent with views by a number of authors that represent the genetic resources of the cultivated species T. alexandrinum, known as Egyptian clover (Berseem). Aaronsohn [35] suggested T. echinatum M. B. from Palestine. Bobrov [36] claimed that T. apertum is the progenitor of T. alexandrinum based on morphological similarities. Putiyevsky et al. [8] considered other species related to T. alexandrinum such as T. vavilovii, T. apertum, T. salmoneum, T. meironense and T. berytheum. On the other hand, Trabut [37] and Eig [38] proposed T. berytheum from the coastal plains of Lebanon as the ancestor of T. alexandrinum. More recently, AFLP data analysis supported a close relationship of T. alexandrinum accessions from Syria and Egypt to T. apertum, T. berytheum and T. salmoneum as well as T. clypeatum, T. plebeium, T. echinatum, T. constantinopolitanum and T. meironense [18].

Ellison et al. [1] also reported the clustering of T. alexandrinum, T. apertum and T. berytheum as well as T. scutatum, T. plebeium, T. vavilovii, T. echinatum and T. salmonium in addition to T. constantinopolitanum. The grouping of T. plebeium, T. berytheum and T. apertum with T. alexandrinum is not well supported in the current results of the section Trifolium phylogeny. In the work of Zohary and Heller [14], T. alexandrinum, is placed in subsection Alexandrina with other four species, i.e., T. apertum, T. berytheum, T. meironense and T. vavilovii, whereas T. plebeium is placed in subsect. Clypeata with T. clypeatum and T. scutatum. In the meantime, T. pallidum is placed in the subsection Trifolium with T. diffusum and T. pratense, whereas T. pannonicum is placed with other six species in subsection Ochroleuca; these species are T. canescens, T. caucasicum, T. caudatum, T. longidentatum, T. ochroleucum and T. trichocephalum. However, in the current study, only T. canescens, T. caucasicum are in clade I while the others are in clade II. The delimitation of these species is generally congruent with their classification in Ellison et al. [1].

The other 19 species of clade I are delimited as a main subclade of 12 species and two small subclades, one of T. berytheum, T. carmeli 1 and 2 and T. meironense, and the other of T. miegeanum, T. obscurum and T. squarrosum. The 12 species in this subclade are differentiated as single branches (Figure 1) and are divided in different subsections by Zohary and Heller [14]; T. berytheum and T. meironense belong to one subsect. Alexandrina and T. carmeli belongs to subsection Echinata. On the other hand, T. miegeanum, T. obscurum and 
T. squarrosum belong to subsection Urceolata. Another two species of the same subsection are separated in clade II; these are T. constantinopolitanum and T. leucanthum.

The clade II of 28 species is differentiated in small subclades based on the ITS data analysis including one clade of four species (T. affine, T. arvense, T. bocconei and T. dalmaticum). The same subclade is also differentiated in the other trees based on the analysis of informative indels of ITS sequence alone or in combination with the morphological data. The delimitation of T. affine, T. arvense, T. bocconei agrees with the results of Ellison et al. [1] but only T. affine, T. arvense are placed in subsect, Arvensia by Zohary and Heller [14], T. bocconei was placed in subsection Trichoptera with T. trichopterum and T. dalmaticum was placed in subsection Scabroidea with T. lucanicum and T. scabrum. In the study of Ellison et al. [1], T. dalmaticum was clustered with T. scabrum and T. lucanicum.

Based on ITS analysis (Figures 1 and 2A), clade III comprises T. hirtum, T. trichopterum, T. haussknechtii and T. sylvaticum, and clade IV comprises T. cherleri and T. scabrum. Combining ITS data with morphological characters, both clades appeared as two subclades of clade III (Figure 2B). In Ellison et al. [1], T. trichopterum was also clustered with T. haussknechtii, and T. sylvaticum, while T. hirtum was clustered with T. cherleri. The clustering of these specie differs with their distribution in the subsections proposed by Zohary and Heller [14], who placed T. cherleri, T. hirtum and T. lappaceum in subsection Lappacea and T. haussknechtii with T. angustifolium. T. dasyurum, T. dichroanthum and T. palaestinum in subsection Angustifolia and grouped T. sylvaticum with T. incarnatum, T. molinerii and T. stellatum in subsection Stellata.

The classification of the species in the section Trifolium in three clades, clade I of 26 species, clade II of 28 species and a small clade III of six species in Figure 2B, is generally comparable to their delimitation by Ellison et al. [1], although these authors regarded the species of the section Trifolium as two clades, A and B. Clade A (25 species) generally corresponds to clade I of the present study, whereas clade B generally corresponds to clade II and clade III of this study. Ellison et al. [1] assumed that interspecific relationships are better resolved within clade B than within clade A. However, the species branching in clade B of Ellison et al. [1] indicate a clade of T. haussknechtii, T. sylvaticum and T. trichopterum, associated with $T$. cherleri and T. hirtum, representing five of the six species differentiated as clade III in the tree constructed using ITS sequence and informative indels in combination with morphological data (Figure 2B).

As circumscribed by Zohary and Heller [14], the section Trifolium is primarily defined by sessile and ebracteate flowers, a hairy or callous ring or a bilabiate protrusion at the throat of the calyx tube, a calyx limb with unequal teeth, a one-seeded pod enclosed in the calyx tube that lacks sutures and ruptures transversely at maturity. The annual life history is the result of some type of time-limitation supporting the shortened life cycle, which is endorsed by inbreeding (Snell and Aarssen [39]. Inbreeding in annuals has evolved as a result of strong re-selection, leading to either selection for a shorter time to complete the reproductive cycle, or selection for shorter pollination time [40]. The habit form affects the level of genetic diversity in Trifolium as the intraspecific genetic variation in annuals is significantly lower than in perennials [41]. Most of the morphological characters give no clear boundaries in the sub-sectional classification of the section Trifolium. Most of the flowering heads are ovoid in the terminal position, with a few species having mixed, terminal and axil flowering heads. Additionally, most of the species has solitary flowering heads on each branch. As for the flower, the corolla is slightly larger than calyx or about twice its length; however, in some species, corolla is equal to the calyx. Most of the species have sharp calyx teeth. The calyx is mostly 10-nerved but few species have 15-20-nerved calyxes; however, the distribution of calyx nerves is not associated with the sub-sectional delimitation of the species, as proposed by Zohary and Heller [14], or their delimitation based on the classification of species based on molecular data [1,16]. Meanwhile, the use of morphological traits in the constructions of phylogenetic relationships of the species in the section Trifolium led to stabilization of the tree topology when combined with the ITS data as shown by Figure 2B. 
Table 1. Section Trifolium species chromosome numbers and proposed sub-sectional delimitation as proposed by Zohary and Heller [14] and the corresponding classification as three clades in the current study. The listed chromosome numbers searched in the Chromosome Counts Database: http:/ / ccdb.tau.ac.il/Angiosperms/Leguminosae/Trifolium/ and the Missouri Botanical Garden (accessed on 15 June 2021). http: / / legacy.tropicos.org/Name/40018244?projectid=9 (accessed on 15 June 2021). The $2 \mathrm{n}$ cromosomes counts for the following five species were taken from the refrence for each species as follows: T. apertum [42] T. dasyurum [43], T. dichroanthum [14], T. carmeli [44], T. trichocephalum [14], T. haussknechtii [45].

\begin{tabular}{|c|c|c|c|}
\hline Trifolium Species & 2n Chromosome Number & Subsection & New Clade \\
\hline T. alexandrinum & 16 & \multirow{5}{*}{ Alexandrina } & \multirow{24}{*}{ Clade I } \\
\hline T. vavilovii & 16 & & \\
\hline T. apertum & 16 & & \\
\hline T. berytheum & 16 & & \\
\hline T. meironense & 16 & & \\
\hline T. scutatum & 10,16 & \multirow{3}{*}{ Clypeata } & \\
\hline T. clypeatum & 16 & & \\
\hline T. plebeium & 16 & & \\
\hline T. pallidum & 16 & Trifolium & \\
\hline T. lucanicum & - & Scabroidea & \\
\hline T. dasyurum & 16 & \multirow{5}{*}{ Angustifolia } & \\
\hline T. dichroanthum & 16 & & \\
\hline T. palaestinum & 16 & & \\
\hline T. angustifolium & $14,16,32$ & & \\
\hline T. purpureum & 14,16 & & \\
\hline T. carmeli & 14 & \multirow{2}{*}{ Echinata } & \\
\hline T. echinatum & 16 & & \\
\hline T. canescens & - & \multirow{3}{*}{ Ochroleuca } & \\
\hline T. caucasicum & - & & \\
\hline T. pannonicum & $64,96,98 \sim 180$ & & \\
\hline T. miegeanum & 16 & \multirow{4}{*}{ Urceolata } & \\
\hline T. obscurum & 16 & & \\
\hline T. squarrosum & 16 & & \\
\hline T. constantinopolitanum & 16 & & \\
\hline T. striatum & 14 & Stenosemium & \multirow{9}{*}{ Clad II } \\
\hline T. latinum & 16 & Echinata & \\
\hline T. alpestre & 16 & \multirow{2}{*}{ Alpesteria } & \\
\hline T. rubens & 16 & & \\
\hline T. medium & $48,64,78,80,84,96,98,126$ & \multirow{5}{*}{ Intermedia } & \\
\hline T. heldreichianum & 16 & & \\
\hline T. patulum & - & & \\
\hline T. velebiticum & - & & \\
\hline T. wettsteinii & - & & \\
\hline
\end{tabular}


Table 1. Cont.

\begin{tabular}{|c|c|c|c|}
\hline Trifolium Species & 2n Chromosome Number & Subsection & New Clade \\
\hline T. caudatum & - & \multirow{4}{*}{ Ochroleuca } & \\
\hline T. longidentatum & - & & \\
\hline T. trichocephalum & 14,28 & & \\
\hline T. ochroleucum & 16 & & \\
\hline T. gemellum & 14 & \multirow{3}{*}{ Pheloidea } & \\
\hline T. phleoides & 14 & & \\
\hline T. ligusticum & 12 & & \\
\hline T. leucanthum & 14,16 & Urceolata & \\
\hline T. diffusum & 16 & \multirow{2}{*}{ Trifolium } & \\
\hline T. pratense & $14,16,28,56$ & & \\
\hline T. molinerii & 14 & \multirow{3}{*}{ Stellata } & \\
\hline T. incarnatum & 14 & & \\
\hline T. stellatum & 14 & & \\
\hline T. lappaceum & 16 & Lappacea & \\
\hline T. affine & $12,14,16$ & \multirow{2}{*}{ Arvensia } & \\
\hline T. arvense & 14 & & \\
\hline T. bocconei & 12,14 & Trichoptera & \\
\hline T. dalmaticum & 10 & Scabroidea & \\
\hline T. sylvaticum & 14,16 & Stellata & \multirow{6}{*}{ Clade III } \\
\hline T. hirtum & 10 & \multirow{2}{*}{ Lappacea } & \\
\hline T. cherleri & 10 & & \\
\hline T. haussknechtii & 16 & Angustifolia & \\
\hline T. scabrum & 10,16 & Scabroidea & \\
\hline T. trichopterum & 14 & Trichoptera & \\
\hline
\end{tabular}

The section Trifolium has been shown to be heterogeneous in seed proteins [17], and chromosome numbers of $2 \mathrm{n}=16,14,12$ or 10 have been reported for the species in the genus $[14,17,23,24,26]$. It is, however, evident that the vast majority of species in clade $\mathrm{I}$ have $2 n=16$, whereas a diploid number of $2 n=14$ was only recorded in T. purpureum; meanwhile, $2 \mathrm{n}=16$ and $2 \mathrm{n}=32$ were recorded for T. angustifolium. On the other hand, in clade II, 14 of the 28 species of clade II have $2 n=10,2 n=12$ and $2 n=14$ and seven species have only $2 n=16$. A diploid number of $2 n=14$ was recorded in twelve species of clade II, but in three of them $2 n=16$ was also recorded. The seven species in which only $2 n=14$ was recorded are T. molinerii, T. phleoides, T. striatum, T. gemellum, T. stellatum, T. incarnatum and T. arvense. In T. dalmaticum, $2 \mathrm{n}=10$ was scored and in T. affine, $2 \mathrm{n}=12$ and $2 \mathrm{n}=16$ were also scored. Of the six species delimited as clade III, $2 \mathrm{n}=10$ was scored in T. cherleri, T. hirtum and T. scabrum, and $2 \mathrm{n}=14$ was scored in T. sylvaticum and T. trichopterum. Polyploidy based on $x=8$ has been reported in only three species, i.e., T. medium, T. pannonicum and T. pratense. Integration of linkage and chromosome maps for the latter species demonstrated chromosomal collinearity among allogamous varieties and should provide valuable insight into allogamous legume genetics [46].

The majority of Trifolium species have a basic chromosome number of $x=8$, which is regarded as the primitive basic number of the genus $[14,17,25]$. Assuming that $x=8$ is the basic number for the genus Trifolium, from which $x=7,6$ and 5 were derived through successive aneuploidy events, species in clade III and clade II may be regarded 
as more evolved than species in clade I. In the genus as a whole, species with $x=8$ are found in all eight sections of Zohary and Heller [14], while $x=7$ is confined to section Chronosemium, section Trifolium and section Trichocephalum, and $x=6$ and 5 to the latter two sections only. These two sections may be regarded the most advanced sections of the genus. However, the conflicting reports of different chromosome numbers for the same species as given in Table 1 make it difficult to conclude phylogenetic relationships based on chromosome number variations from the published literature. Moreover, careful identification of material used in addressing systematics and phylogeny of species in Trifolium must be thoughtfully checked by careful morphological description.

In conclusion, the grouping of species as reported here and by Ellison et al. [1] does not support the delimitation of species in the section Trifolium in 17 subsections as described by Zohary and Heller [14]. The species of subsections Alexandrina and Clypeata, in addition to most of the species of subsections Angustifolia, Echinata and Urceolata and half of the species of subsection Ochroleuca, are grouped in clade I of the present study. Additionally, the species of subsections Alpesteria, Intermedia, Phleoidea, Arvensia and Stenosemium (T. striatum) are grouped together in clade II. The remaining species are distributed in the three clades. In the genus Trifolium, the basic number of $x=8$ is the number from which $x=7,6$ and 5 were derived through successive aneuploidy events. With reference to the distribution of these numbers in the section Trifolium, species in clade III and clade II appear to be more evolved than species in clade I.

\section{Material and Methods}

\subsection{Plant Material}

Seed material of 60 of the 73 species of the section Trifolium was obtained from a variety of sources (Table 2). Seeds were germinated and grown to maturity at the Botanic Garden of Miami University, Oxford Ohio, USA, to confirm their taxonomic status. Voucher specimens of all species are deposited at the Willard Sherman Turrell Herbarium of Miami University. Ten morphological traits were used as diagnostic characters with reference to their description by Zohary and Heller [14].

Table 2. Trifolium species names, source and accession number *, country of origin and Gene Bank submission number for ITS1/ITS2 sequences.

\begin{tabular}{|c|c|c|c|c|}
\hline No & Trifolium Species & $\begin{array}{c}\text { Source and Accession } \\
\text { Number * }\end{array}$ & Country of Origin & Gene Bank ITS1/ITS2 \\
\hline 1 & T. affine Presl. & SRPIS 369014 & Turkey & MW683982/MW684022 \\
\hline 2 & T. alexandrinum $\mathrm{L}$. & ARC, EG 10 & Egypt & AF154381/AF154605 \\
\hline 3 & T. alpestre L. & Kew 11097 & Switzerland & AF154400/AF154624 \\
\hline 4 & T. angustifolium L. & MU 9491 & USA & MW683983/MW684023 \\
\hline 5 & T. angustifolium L. & BGUZ 8023 & Switzerland & AF154388/AF154612 \\
\hline 6 & T. apertum Bobrov & SRPIS 314117 & Russia & MW683984/MW684024 \\
\hline 7 & T. arvense $\mathrm{L}$. & SRPIS 120077 & Turkey & MW683985/MW684025 \\
\hline 8 & T. berytheum Bois. and T. Blanche & SRPIS 369019 & Turkey & MW683986/MW684026 \\
\hline 9 & T. bocconei Savi & SRPIS 224643 & Morocco & MW683987/MW684027 \\
\hline 10 & T. canescens Willd. & WRPIS 418866 & Italy & MW683988/MW684028 \\
\hline 11 & T. carmeli Boiss. & IPK TRIF 100/75 & USA & MW683989/MW684029 \\
\hline 12 & T. carmeli & SRPIS 353422 & Israel & MW683990/MW684030 \\
\hline 13 & T. caucasicum Tausch* & WRPIS 597496 & Russia & MW683991/MW684031 \\
\hline 14 & T. caudatum Boiss. & WRPIS 251858 & Italy & MW683992/MW684032 \\
\hline
\end{tabular}


Table 2. Cont.

\begin{tabular}{|c|c|c|c|c|}
\hline No & Trifolium Species & $\begin{array}{c}\text { Source and Accession } \\
\text { Number * }\end{array}$ & Country of Origin & Gene Bank ITS1/ITS2 \\
\hline 15 & T. cherleri L. & Italy 589 & Italy & AF154357/AF154582 \\
\hline 16 & T. clypeatum L. & ICARDA 1149 & Syria & AF154383/AF154607 \\
\hline 17 & T. constantinopolitanum Sert. & ICARDA 1114 & Syria & AF154386/AF154610 \\
\hline 18 & T. dalmaticum Vis. & WRPIS 516292 & Serbia & MW683993/MW684033 \\
\hline 19 & T. dasyurum C. Presl. & SRPIS 369029 & Australia & AF154387/AF154611 \\
\hline 20 & T. dichroanthum Boiss. & SRPIS 292474 & Israel & MW683994/MW684034 \\
\hline 21 & T. diffusum Ehrh. & Kew 1094 & Serbia & AF154401/AF154625 \\
\hline 22 & T. echinatum N.B. & ICARDA 1758 & Syria & AF154382/AF154606 \\
\hline 23 & T. gemellum Willd. & SRPIS 302967 & Spain & MW683995/MW684035 \\
\hline 24 & T. haussknechtii Boiss. & WRPIS G31176-98i & Bulgaria & MW683996/MW684036 \\
\hline 25 & T. heldreichianum Hausskn. & WRPIS 419289 & Greece & MW683997/MW684037 \\
\hline 26 & T. hirtum All. & Kew 25085 & Greece & AF154359/AF154932 \\
\hline 27 & T. incarnatum L. & Kew 55767 & England & AF154392/AF154932 \\
\hline 28 & T. lappaceum L. & ICARDA 108405 & Syria & MW683998/MW684038 \\
\hline 29 & T. lappaceum L.. & Italy 529 & Italy & AF154395/AF154619 \\
\hline 30 & T. latinum Sebast. & IOWA State & USA & MW683999/MW684039 \\
\hline 31 & T. leucanthum M.B. & ICARDA 1111 & Syria & AF154394/AF154618 \\
\hline 32 & T. ligusticum Lois. & SRPIS 419415 & Greece & MW684000/MW684040 \\
\hline 33 & T. longidentatum Nabelek & WRPIS 542831 & Bosnia, Herzegovina & MW684001/MW684041 \\
\hline 34 & T. lucanicum Gasp. Ex Guss. & Kew 13921 & Greece & AF154390/AF154614 \\
\hline 35 & T. medium. L. & WRPIS 325481 & Russia & MW684002/MW684042 \\
\hline 36 & T. meironense Zoh. and Lern. & ICARDA 69062 & Algeria & MW684003/MW684043 \\
\hline 37 & T. miegeanum Maire & SRPIS 258406 & Portugal & MW684004/MW684044 \\
\hline 38 & T. molinerii (incarnatum L.) & SRPIS 591667 & Bulgaria & MW684005/MW684045 \\
\hline 39 & T. obscurum Savi & SRPIS 369057 & Italy & MW684006/MW684046 \\
\hline 40 & T. ochroleucum Huds. & Kew 7559 & Greece & AF154397/AF154621 \\
\hline 41 & T. palaestinum Boiss. & SRPIS 369060 & Palestine & MW684007/MW684047 \\
\hline 42 & T. pallidum Waldst. and Kit. & Kew 31516 & Greece & AF154385/AF154609 \\
\hline 43 & T. pannonicum Jacq. & BGUZ s.n. & Switzerland & AF154384/AF154608 \\
\hline 44 & T. patulum Tausch & WRPIS 604678-97i & Serbia & MW684008/MW684048 \\
\hline 45 & T. phleoides Willd. & SRPIS 298420 & Turkey & MW684009/MW684049 \\
\hline 46 & T. plebeium Boiss. & ICARDA 67905 & Syria & MW684010/MW684050 \\
\hline 47 & T. pratense $\mathrm{L}$. & JBVU 1044 & France & AF154396/AF154620 \\
\hline 48 & T. purpureum Loisel & ICARDA 938 & Syria & AF154389/AF154613 \\
\hline 49 & T. rubens L. & IPP 135 & France & AF154398/AF154622 \\
\hline 50 & T. scabrum L. & ICARDA 939 & Syria & AF154358/AF154583 \\
\hline 51 & T. scutatum Boiss. & ICARDA 67459 & Syria & MW684011/MW684051 \\
\hline 52 & T. squarrosum $\mathrm{L}$. & SRPIS 233720 & Italy & MW684012/MW684052 \\
\hline
\end{tabular}


Table 2. Cont.

\begin{tabular}{ccccc}
\hline No & Trifolium Species & $\begin{array}{c}\text { Source and Accession } \\
\text { Number }\end{array}$ & Country of Origin & Gene Bank ITS1/ITS2 \\
\hline 53 & T. stellatum L. & ICARDA 947 & Syria & AF154393/AF154617 \\
\hline 54 & T. striatum L. & Kew 5337 & England & AF154391/AF154615 \\
\hline 55 & T. sylvaticum Gerard & SRPIS 120194 & Turkey & MW684013/MW684053 \\
\hline 56 & T. trichocephalum Bieb. & WRPIS 251210-64 & North Macedonia & MW684014/MW684054 \\
\hline 57 & T. trichopterum Pancic & SRPIS 583430 & Bulgaria & MW684015/MW684055 \\
\hline 58 & T. vavilovii Eig & Vencent 11160 & USA & MW684016/MW684056/ \\
\hline 59 & T. velebiticum Degen & WRPIS G30679-97i & USA & MW684017/MW684057 \\
\hline 60 & T. wettsteinii Dorfl. and Hay & WRPIS G31121 & USA & MW684018/MW684058 \\
\hline
\end{tabular}

ARCE = Agriculture Research Center, Cairo, Egypt. BGUZ = Botanischer Gaten der Universität Zurich, Switzerland. ICARDA = International Center for Agricultural Research in Dry Areas, Aleppo, Syria. ICLA = International Livestock Center for Africa, Addis Ababa, Ethiopia. IPP = University of Bayreuth Botanic Garden, Germany. Italy = Universita di Siena, Italy. JBVU = Jardin Botanique de la Ville et de I'Universite, France. Kew = Royal Botanic Garden, Kew, Richmond, Surry, London. UK. MU = Miami University, Oxford Ohio, USA. SRPIS = South Regional Plant Introduction Station, USA. WRPIS = South Regional Plant Introduction Station, USA.

\subsection{DNA Isolation and DNA Sequence}

For ITS sequencing, total genomic DNA was isolated from fresh leaves of seedlings using the $2 X$ CTAB procedure [47]. A few leaflets were powdered, in liquid nitrogen, using mortar and pestle, and homogenized in $0.75 \mathrm{~mL}$ of hot $4 \times$ CTAB buffer, to which $1 \%$ PVP, $1 \%$ Na-bisulphite and $0.2 \% \beta$-mercaptoethanol were added before use, and transferred to $2.0 \mathrm{~mL}$ microfuge. The tubes were incubated for $30 \mathrm{~min}$ at $60^{\circ} \mathrm{C}$ in a water bath with occasional gentle mixing. After incubation, the mixture was emulsified with $0.5 \mathrm{~mL}$ of chloroform-isoamyl alcohol (24:1) and centrifuged at 10,000 $\mathrm{g}$ for $5 \mathrm{~min}$. The aqueous top layer was pipetted into a new tube, mixed with $0.5 \mathrm{~mL}$ cold isopropanol, kept at $-20^{\circ} \mathrm{C}$ for $30 \mathrm{~min}$ and centrifuged at 12,000 $\mathrm{g}$ for $10 \mathrm{~min}$. The alcohol was discarded, and the pellet was washed in $0.75 \mathrm{~mL} 76 \% \mathrm{EtOH} / 0.01 \mathrm{M} \mathrm{NH}_{4} \mathrm{OAC}$ for $5 \mathrm{~min}$ followed by washing in $0.75 \mathrm{~mL} 76 \% \mathrm{EtOH} / 0.01 \mathrm{M} \mathrm{NaOAC}$ for a few minutes. The pellet was then dried and suspended in $0.2 \mathrm{~mL}$ TE buffer, $1 \mu \mathrm{L}$ RNase was added to remove RNA and the buffer extract was kept at $37^{\circ} \mathrm{C}$ for 30 min before using DNA for ITS amplification.

The ITS region was amplified using primers of White et al. [48]. The spacers were sequenced on an ABI PRISM $310^{\circledR}$ Genetic Analyzer using capillary sequencing and Big Dye Terminator Chemistry (Applied Biosystems, Inc., Foster City, CA, USA). The sequence boundaries of the spacers were determined by comparison to published Trifolium sequences [1,16] and complete sequences were deposited in GenBank (Table 2). All ITS sequences were aligned using Clustal [49], with manual gap adjustments made to improve the alignment. Indels were coded following Simmons and Ochoterena [50] using the Gap Coder software [51].

\subsection{Phylogenetic Analysis}

Two approaches were used to express the phylogenetic relationships of the examined species based on the molecular ITS sequencing alone and in combination with the morphological characters coded as multistate matrix (supplementary Table S1). The Bayesian analysis expressing the cladogenesis of species was expressed as cluster using the software MrBayes 3.2 [32]. The best-fit substitution model ( $\mathrm{SYM}+\mathrm{G})$ was chosen based on the Akaike Information criterion (AIC) as determined by the MrModel-test v.2.3 [52]. The Markov chain Monte Carlo (MCMC) process was run for 3,000,000 generations and trees were sampled every 1000 generations with 16 chains. Stationarity was accomplished when "the average standard deviation of split frequencies" remained $<0.01$; the first $25 \%$ of runs were discarded. The phylogenetic tree established with MrBayes 3.2 was represented with Interactive Tree of Life (iTOL) tools [33] and TreeGraph 2 software [34]. 
Supplementary Materials: The following are available online at https:/ / www.mdpi.com/article/10 .3390 / plants10101985/s1, Table S1: Morphological characters of the examined Trifolium species and their recorded $2 \mathrm{n}$ chro-mosome numbers.

Author Contributions: H.I.S.A.: visualization methodology, data analysis. A.B.: conceptualization, visualization, writing-reviewing and editing. H.H.E.-S.: visualization, investigation. L.W.: supervision. software. A.S.F.: software, reviewing and editing, submission. F.Y.E.: software, data analysis. All authors have read and agreed to the published version of the manuscript.

Funding: This research received no external funding.

Institutional Review Board Statement: Not applicable for this section.

Informed Consent Statement: Not applicable.

Data Availability Statement: Date is contained within the article.

Acknowledgments: A.B. acknowledges the Fulbright Foundations and HH thanks the International Office of Miami University, Oxford, OH, USA for funding their travel to the US.

Conflicts of Interest: The authors declare that they have no competing interest.

\section{References}

1. Ellison, N.W.; Liston, A.; Steiner, J.J.; Williams, W.M.; Taylor, N.L. Molecular phylogenetics of the clover genus (TrifoliumLeguminosae). Mol. Phylogenet. Evol. 2006, 39, 688-705. [CrossRef]

2. Gillett, J.M.; Taylor, N.L.; Collins, M. World of Clovers; Collins, M., Ed.; Iowa State, University Press: Ames, IA, USA, 2001.

3. Scoppola, A.; Tirado, J.L.; Gutiérrez, F.M.; Magrini, S. The genus Trifolium (Fabaceae) in south Europe: A critical review on species richness and distribution. Nord. J. Bot. 2018, 36, njb-01723. [CrossRef]

4. Sprent, J.I.; Platzmann, J. Nodulation in Legumes; Royal Botanic Gardens Kew: London, UK, 2001.

5. Taylor, N.; Smith, R. Red clover breeding and genetics. In Advances in Agronomy; Elsevier: Amsterdam, The Netherlands, 1980; Volume 31, pp. 125-154.

6. Katznelson, J.; Putiyevsky, E. Cytogenetic studies in trifolium spp. related to berseem II. Relationships within the echinata group. Theor. Appl. Genet. 1974, 44, 87-94. [CrossRef] [PubMed]

7. Putiyevsky, E.; Katznelson, J. Cytogenetic studies in Trifolium spp. related to berseem I. Intra- and interspecific hybrid seed formation. Theor. Appl. Genet. 1973, 43, 351-358. [CrossRef] [PubMed]

8. Putiyevsky, E.; Katznelson, J.; Zohary, D. Cytogenetic studies in Trifolium spp related to Berseem. IV. The relationships in the Alexandrinum and Vavilovi crossability groups and the origin of cultivated Berseem. Theor. Appl. Genet. 1975, 45, 355-362. [CrossRef] [PubMed]

9. Taylor, N.L.; Quesenberry, K.H. Red Clover Science. In Current Plant Sciences and Biology in Agriculture; Kluwer Academic Publisher: Dordrecht, The Netherlands, 1996; Volume 28, pp. 141-160.

10. Williams, W.M.; Ellison, N.W.; Ansari, H.A.; Verry, I.M.; Hussain, S.W. Experimental evidence for the ancestry of allotetraploid Trifolium repens and creation of synthetic forms with value for plant breeding. BMC Plant Biol. 2012, 12, 1-10. [CrossRef]

11. Morris, J.; Greene, S. Defining a Multiple-Use Germplasm Collection for the Genus Trifolium. Crop Sci. 2001, 41, 893-901. [CrossRef]

12. Boissier, E. Trifolium. In Flora Orientalis, Sive, Enumeratio Plantarum in Oriente a Graecia et Aegypto ad Indiae Fines Hucusque Observatarum; Georg, H., Ed.; Basileae: Genevae, Switzerland, 1872; Volume 2.

13. Zohary, M. Origins and evolution in the genus. Trifolium. Bot. Notiser. 1972, 125, 501-511.

14. Zohary, M.; Heller, D. The Genus Trifolium; Israel Academy of Sciences and Humanities: Jerusalem, Israel, 1984.

15. Goldblatt, P.; Johnson, D.E. Tropicos Database: Index to Plant Chromosome Numbers. 2001-2003; Missouri Botanical Garden: St Louis, MO, USA, 2006.

16. Watson, L.; Sayed-Ahmed, H.; Badr, A. Molecular phylogeny of Old World Trifolium (Fabaceae), based on plastid and nuclear markers. Plant Syst. Evol. 2000, 224, 153-171. [CrossRef]

17. Badr, A. Electrophoretic studies of seed proteins in relation to chromosomal criteria and the relationships of some taxa of Trifolium. Taxon 1995, 44, 183-191. [CrossRef]

18. Badr, A.; El-Shazly, H.H.; Watson, L.E. Origin and ancestry of Egyptian clover (Trifolium alexandrinum L.) as revealed by AFLP markers. Genet. Resour. Crop Evol. 2008, 55, 21-31. [CrossRef]

19. Jombart, T. adegenet: A R package for the multivariate analysis of genetic markers. Bioinformatics 2008, 24, 1403-1405. [CrossRef]

20. Zoric, L.; Merkulov, L.; Lukovic, J.; Boza, P. Comparative analysis of qualitative anatomical characters of Trifolium L.(Fabaceae) and their taxonomic implications: Preliminary results. Plant Syst. Evol. 2012, 298, 205-219. [CrossRef]

21. Tripp, E.A.; Lendemer, J.C. Sleepless nights: When you can't find anything to use but molecules to describe new taxa. Taxon 2014, 63, 969-971. [CrossRef]

22. Senn, H.A. Chromosome number relationship Leguminosae. Bibliogr. Genet. 1938, 12, 175-336. 
23. Britten, E.J. Chromosome numbers in the genus Trifolium. Cytologia 1963, 28, 428-449. [CrossRef]

24. Pritchard, R.D. Equity theory: A review and critique. Organ. Behav. Hum. Decis. Process. 1969, 4, 176-211. [CrossRef]

25. Goldblatt, P. Cytology and Phylogeny of Leguminosae; Polhill, R.M., Raven, P.H., Eds.; Royal Botanic Gardens: Kew, UK, 1981; Volume 2, pp. 427-463.

26. El-Kholy, M. Cytology of Some Trifolium Species; Al-Azhar University: Cairo, Egypt, 1990.

27. Bermúdez-Torres, K.; Ferval, M.; Hernández-Sánchez, A.M.; Tei, A.; Gers, C.; Wink, M.; Legal, L. Molecular and Chemical Markers to Illustrate the Complex Diversity of the Genus Lupinus (Fabaceae). Diversity 2021, 13, 263. [CrossRef]

28. Khalili, Z.; Ghalenoyi, S.; Maassoumi, A.A.; Kazempour-Osaloo, S. Phylogenetic relationships, biogeography and taxonomic delimitation of Astragalus sect. Acanthophace (Fabaceae) using cpDNA and nrDNA ITS sequences analyses. Plant Biosyst. 2021, 155, 291-301.

29. Ashkenazy, H.; Cohen, O.; Pupko, T.; Huchon, D. Indel reliability in indel-based phylogenetic inference. Genome Biol. Evol. 2014, 6, 3199-3209. [CrossRef]

30. Kalinkina, V.A.; Mikhaylova, Y.V.; Kislov, D.E. Diversity and taxonomy of the Trifolium lupinaster polymorphic complex in Eastern Europe and Asia. Flora 2020, 267, 151597. [CrossRef]

31. Jreisat, C.S.; Laten, H.M. Ribosomal RNA Internal Transcribed Regions Identify Possible Misidentification or Mislabeling among Trifolium (Clover) Specimens from Germplasm Collections. Crop Sci. 2017, 57, 322-326. [CrossRef]

32. Ronquist, F.; Teslenko, M.; Van Der Mark, P.; Ayres, D.L.; Darling, A.; Höhna, S.; Larget, B.; Liu, L.; Suchard, M.A.; Huelsenbeck, J.P. MrBayes 3.2: Efficient Bayesian phylogenetic inference and model choice across a large model space. Syst. Biol. 2012, 61, 539-542. [CrossRef] [PubMed]

33. Letunic, I.; Bork, P. Interactive Tree Of Life (iTOL) v5: An online tool for phylogenetic tree display and annotation. Nucleic Acids Res. 2021, 49, W293-W296. [CrossRef] [PubMed]

34. Stöver, B.C.; Müller, K.F. TreeGraph 2: Combining and visualizing evidence from different phylogenetic analyses. BMC Bioinform. 2010, 11, 1-9. [CrossRef]

35. Aaronsohn, A. Agricultural Explorations in Palestine; USDA: Washington, DC, USA, 1910; 80.

36. Bobrov, E. Vidi Kleverov URSS (in Russian). Acta Inst. Bot. N. Acad. Sci. USSR Ser. 1 1947, 6, 164-336.

37. Trabut, M. L'indigénat de la Fève en Algérie. Bull. Soc. Bot. Fr. Rev. Bibl. 1910, 57, 424-429. [CrossRef]

38. Eig, A. A historical-phytosociological essay on Palestine forests of Quercus aegilops L. ssp.ithaburensis (Des) in past and present. Beih. Bot. Cent. 1934, 51B, 225-272.

39. Snell, R.; Aarssen, L.W. Life history traits in selfing versus outcrossing annuals: Exploring the 'time-limitation' hypothesis for the fitness benefit of self-pollination. BMC Ecol. 2005, 5, 1-14. [CrossRef]

40. Aarssen, L. Why are most selfers annuals? A new hypothesis for the fitness benefit of selfing. Oikos 2000, 89, 606-612. [CrossRef]

41. Nosrati, H.; Feizi, M.H.; Razban-Haghighi, A.; Seyed-Tarrah, S. Impact of life history on genetic variation in Trifolium (Fabaceae) estimated by ISSR. Environ. Exp. Biol. 2015, 13, 83-88.

42. Malaviya, D.R.; Roy, A.K.; Kaushal, P.; Kumar, B. Affinity between Trifolium alexandrinum and T. apertum-cytological investigation in embryo rescued hybrid. Cytologia 2004, 69, 425-429. [CrossRef]

43. Riasat, M.; Sadeghian, S. Karyology Study of Ten Trifolium Species in Fars Province. J. Genet. Res. 2019, 5, 136-142.

44. Kazimierski, T.; Kazimierska, E. Structure of anther heads in some Trifolium L. species. Acta Soc. Bot. Pol. 1974, 43, 321-329. [CrossRef]

45. Kiran, Y.; Şahİn, A.; Türkoğlu, İ.; Emre, İ.; Kurşat, M. Karyological notes on seven Trifolium L. taxa from Turkey. Turk. J. Sci. Technol. 2015, 10, 11-16.

46. Kataoka, R.; Hara, M.; Kato, S.; Isobe, S.; Sato, S.; Tabata, S.; Ohmido, N. Integration of linkage and chromosome maps of red clover (Trifolium pratense L.). Cytogenet. Genome Res. 2012, 137, 60-69. [CrossRef] [PubMed]

47. Doyle, J.J.; Doyle, J.L. A rapid DNA isolation procedure for small quantities of fresh leaf tissue. Phytochem. Bull. 1987, 19, 11-15.

48. White, T.J.; Bruns, T.; Lee, S.; Taylor, J. Amplification and direct sequencing of fungal ribosomal RNA genes for phylogenetics. In PCR Protocols: A Guide to Methods Applications; Innis, M.A., Gelfand, D.H., Snisky, J.J., White, T.J., Eds.; Academic Press: San Diego, CA, USA, 1990; Volume 18, pp. 315-322.

49. Higgins, D.G.; Bleasby, A.J.; Fuchs, R. CLUSTAL V: Improved software for multiple sequence alignment. Bioinformatics 1992, 8, 189-191. [CrossRef]

50. Simmons, M.P.; Ochoterena, H. Gaps as characters in sequence-based phylogenetic analyses. Syst. Biol. 2000, 49, 369-381. [CrossRef]

51. Young, N.D.; Healy, J. GapCoder automates the use of indel characters in phylogenetic analysis. BMC Bioinform. 2003, 4, 1-6. [CrossRef]

52. Posada, D.; Crandall, K.A. Modeltest: Testing the model of DNA substitution. Bioinformatics 1998, 14, 817-818. [CrossRef] [PubMed] 